\title{
SURVIVAL, GROWTH AND MYCORRHIZATION OF CONTAINERISED PINUS SYLVESTRIS AND PICEA ABIES SEEDLINGS OF DIFFERENT PROVENANCES OUTPLANTED IN A FOREST CLEAR-CUT
}

\author{
Dārta Klaviṇa ${ }^{1, \#}$, Indrik̦is Muižnieks² ${ }^{2}$ Imants Baumanis ${ }^{1}$, Jurğis Jansons ${ }^{1}$, \\ Tālis Gaitnieks ${ }^{1}$, and Audrius Menkis ${ }^{3}$ \\ ${ }^{1}$ Latvian State Forest Research Institute "Silava", 111 Rigas Str., Salaspils, LV-2169, LATVIA \\ ${ }^{2}$ Faculty of Biology, University of Latvia, 1 Jelgavas Str., Riga, LV-1004, LATVIA \\ ${ }^{3}$ Uppsala BioCenter, Department of Forest Mycology and Pathology, Swedish University of Agricultural Sciences, \\ P.O. Box 7026, SE-75007, Uppsala, SWEDEN \\ \# Corresponding author, darta.klavina@silava.lv
}

Contributed by Tālis Gaitnieks

\begin{abstract}
We studied field performance of containerised Pinus sylvestris and Picea abies seedlings of different provenances. Shoot height, needle chemical composition, root collar diameter, root mycorrhization and mycorrhizal species composition were evaluated after four growing seasons following outplanting. The results showed that in general spruce had better survival than pine. Ectomycorrhizas on spruce were dominated by Wilcoxina, Amphinema and Tylospora, while on pine - by Suillus and Thelephora species. Spruce and pine showing best growth rates were colonised by ectomycorrhizal fungus Amphinema sp. In conclusion, the results demonstrated that forest nursery practices as well as provenance can significantly impact survival, growth and mycorrhization of the containerised pine and spruce seedlings.
\end{abstract}

Key words: Scots pine, Norway spruce, ectomycorrhizal fungi, forest nursery, seed origin.

\section{INTRODUCTION}

Scots pine (Pinus sylvestris L.) and Norway spruce (Picea abies (L.) Karst.) are the most common and predominantly used tree species in reforestation in Latvia. State forest nurseries in Latvia produce approx. 40 million $P$. sylvestris and $P$. abies seedlings yearly and more than half of these are cultivated containerised (personal communication, Seeds and Plants, Latvia's State Forests Joint Stock Company, JSC). As nursery practices and seed origin can have significant effect on survival and growth of replanted tree seedlings (Ying, 1991; Óskarssonand and Brynleyfsdóttir, 2009; Klavina et al., 2015), use of local seed provenances is often recommended for seedling cultivation in Latvia (Gailis, 1993).

Ectomycorrhizal (ECM) fungi are known to provide nutritional benefits to the seedlings and promote their survival and growth in the field (Le Tacon et al., 1994; Menkis et al., 2007; 2012). However, intensive management practices (often fertilization, application of pesticides for weed and pest control, etc.) in forest nurseries may often result in both reduced ECM colonisation of seedling roots and species di- versity (Nilsson and Wallander, 2003), and only a limited number of ECM fungi can tolerate such growth conditions (Menkis and Vasaitis, 2011). A number of studies have shown importance of host genotype to richness and abundance of ECM fungi associated with seedling roots (Korkama et al., 2006; Leski et al., 2010; Velmala et al., 2013), indicating that selection of particular tree genotype or seed provenance may improve ECM colonisation of seedling roots and eventually their better performance after outplanting.

The aim of the present study was to assess survival, growth and mycorrhization of containerised $P$. sylvestris and $P$. abies seedlings produced from different seed provenances in three different forest nurseries in Latvia four years following their outplanting on a forest clear-cut.

\section{MATERIALS AND METHODS}

Experimental planting. The experimental plantation (2500 $\mathrm{m}^{2}$ in size) was established on a clear-cut (N56 $51^{\prime}$ E23 $\left.3^{\circ} 47^{\prime}\right)$ in Tìreḷi forest district (managed by Riga Forests, Limited 
Liability Company, LLC) in central Latvia. The site was a northern temperate forest of an Oxalido-myrtilliosa forest type. The forest stand before clear-felling in 2005 was dominated by $P$. abies. Soil at the site was conifer forest podzol $\left(\mathrm{pH}_{\mathrm{KCl}}-5.0\right)$, characterised by the following chemical composition (mg/l of soil): N 30, P 87, K 22, Ca 2550, Mg 213, S 28, Fe 850, Mn 6.5, Zn 1.6, Cu 0.2, Mo 0.06, B 0.1 (Klavina et al., 2013). The experimental plantation was established in May 2006. Before planting, the site was ploughed in 20 rows at intervals of $1.5 \mathrm{~m}$, and seedlings were arranged in parcels in four replicates (45 seedlings in each parcel, resulting in total 180 seedlings from each seedling provenance). Containerized spruce (2-years-old) and pine (1-year-old) seedlings were used for planting. Seedlings were obtained from three forest nurseries, which included the Strenči and Mazsili forest nurseries (S- and M-nursery) (Latvia's State Forests, JSC), which are the two largest forest nurseries in Latvia, and from the forest nursery Norupe (N-nursery) (Riga Forests, LLC), which is the main seedling producer for the Riga region where our plantation plot was located. Seedlings in all nurseries were cultivated in $85 \mathrm{~cm}^{3}$ containers in the greenhouse in sphagnum peat growth substrate. Seedlings used in the present study represented standard planting material of each nursery. Detailed information about planting material and its origin is presented in Table 1 and Figure 1.

Seedling measurements and sampling. After the fourth growing season, in October 2009, shoot height and root collar diameter was measured for each seedling. Dead or damaged seedlings were excluded from the experiment. For determination of chemical composition of needles, ten needles per plant were taken from ten random plants of each seedling provenance in October 2009, pooled together and analysed as a bulk sample using protocol described previously (Klavina et al., 2013). Roots of 90 seedlings were collected in October 2009. The number of seedlings analysed for mycorrhization in different provenances was between 7 and 20 and depended on survival rate of seedlings. Roots of each seedling were individually packed into plastic bags together with additional soil, transported to the laboratory and stored at $4{ }^{\circ} \mathrm{C}$ until processed. Within two weeks each sampled root system was gently washed in tap water to remove the soil.

ECM morphotyping and molecular identification of fungal taxa. Ectomycorrhizal root tips were analysed using a Leica MZ-7.5 (Wetzlar, Germany) stereomicroscope. ECM morphotypes were estimated according to morphological characteristics (Agerer, 1986-2006). Presence/absence of different morphotypes was noted for each seedling. For molecular identification of fungal taxa, 1-5 root tips of each distinct ECM morphotype per each seedling provenance were placed in $1.5 \mathrm{ml}$ centrifugation tubes and stored at -16 ${ }^{\circ} \mathrm{C}$. DNA extraction and PCR using primers ITS1F and ITS4 (White et al., 1990) were conducted as in a previous study (Menkis and Vasaitis, 2011). Sequencing was performed by Macrogen Inc., Seoul, Korea and raw sequence data were analysed using the SeqMan Pro version 9.1.0
Table 1

DESCRIPTION OF PINUS SYLVESTRIS AND PICEA ABIES CONTAINERISED SEEDLINGS USED FOR EXPERIMENTAL PLANTING

\begin{tabular}{l|ccc}
\hline \multicolumn{1}{c|}{ Species } & Nursery & Seed region & Seed orchard \\
\hline Pinus sylvestris & Mazsili (M) & Western Latvia & $\overline{\text { Ile (1) }}$ \\
& Norupe (N) & Central Latvia & Olaine (2) \\
& Strenči (S) & Eastern Latvia & Vēžnieki (3) \\
\hline Picea abies & Mazsili (M) & Western Latvia & Remte (4) \\
& Strenči (S) & Central Latvia & Suntaži (5) \\
& Norupe (N) & Eastern Latvia & Stradi (6)
\end{tabular}

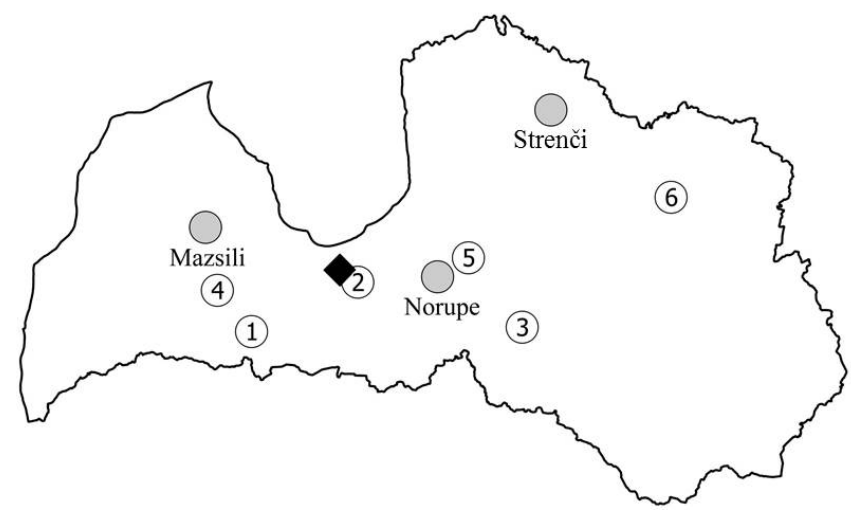

Fig. 1. Map of Latvia showing the experimental planting site indicated by a diamond ( $\bullet$ ), nurseries indicated by filled circles $(\bigcirc)$ and seed orchards indicated by circles with numbers 1-6 (1) ) as in Table 1 .

software from the DNASTAR package (DNASTAR, Madison, WI, USA). Databases at GenBank (Altschul et al., 1997) and UNITE (Kõljalg et al., 2013) were used to determine the identity of ITS rRNA sequences.

Statistical analyses. Relative abundance of ECM morphotypes in each tree species and provenance was calculated from the total number of ECM roots examined; relative abundance of ECM species was calculated for identified species. Survival of different tree species and provenances was compared by chi-square $\left(\chi^{2}\right)$ tests calculated from the actual number of observations (Mead and Curnow, 1983). Significant differences in height, root collar diameter and number of ECM morphotypes among seedling provenances were determined by one-way analysis of variance (ANOVA) and the post-hoc Tukey's test (Fowler et al., 1998). These analyses were performed using R 2.15.3 software (Anonymous, 2011). Shannon diversity indices were used to characterise diversity of fungal communities and qualitative $\left(\mathrm{S}_{\mathrm{S}}\right)$ Sorensen indices to estimate similarity in composition among different treatments (Magurran, 1988). These indices were calculated in ComEcoPaC (Drozd, 2010).

\section{RESULTS}

After four growing seasons in a plantation, initial morphological differences among seedlings from different provenances were still present. At the time of outplanting, spruce 
MORPHOLOGICAL PARAMETERS OF SPRUCE AND PINE SEEDLINGS (SURVIVAL, SHOOT HEIGHT, ROOT COLLAR DIAMETER AND AVERAGE NUMBER OF ECM MORPHOTYPES) AFTER FOUR GROWING SEASONS IN A PLANTATION

\begin{tabular}{llcccc}
\hline \multicolumn{1}{c|}{ Parameter } & Species & S-nursery & M-nursery & N-nursery \\
\hline Survival, \% & Spruce & $51^{\mathrm{b}}$ & $73^{\mathrm{a}}$ & $45^{\mathrm{b}}$ \\
& Pine & 60 & 48 & 48 \\
Seedling height, & Spruce & $84 \pm 3^{\mathrm{b}}$ & $99 \pm 2^{\mathrm{a}}$ & $81 \pm 3^{\mathrm{b}}$ \\
$\mathrm{cm}( \pm$ SE) & Pine & $129 \pm 3^{\mathrm{a}}$ & $118 \pm 3^{\mathrm{b}}$ & $90 \pm 3^{\mathrm{c}}$ \\
Root collar dia- & Spruce & $1.47 \pm 0.03^{\mathrm{b}}$ & $1.78 \pm 0.03^{\mathrm{a}}$ & $1.45 \pm 0.03^{\mathrm{b}}$ \\
meter, cm $( \pm$ SE) & Pine & $2.54 \pm 0.08^{\mathrm{c}}$ & $2.27 \pm 0.06^{\mathrm{b}}$ & $1.61 \pm 0.05^{\mathrm{a}}$ \\
n of ECM & Spruce & $2.6 \pm 0.1^{\mathrm{b}}$ & $2.5 \pm 0.1^{\mathrm{ab}}$ & $2.1 \pm 0.2^{\mathrm{a}}$ \\
$\begin{array}{l}\text { morphotypes per } \\
\text { seedling }( \pm \text { SE })\end{array}$ & Pine & $1.7 \pm 0.2^{\mathrm{a}}$ & $1.9 \pm 0.1^{\mathrm{a}}$ & $1.3 \pm 0.2^{\mathrm{c}}$ \\
\cline { 1 - 2 } & & & &
\end{tabular}

* Different letters indicate significant $(p=0.05)$ difference among seedling parameters ECM, ectomycorrhizal

seedlings from the M-nursery were significantly taller than seedlings from the other two nurseries (mean height: $39 \pm 4$ $\mathrm{cm}$ (M-nursery); $24 \pm 4 \mathrm{~cm}$ (S-nursery) and $23 \pm 3 \mathrm{~cm}$ (N-nursery)) and height of seedlings showed the same differences at the end of the experimental period (Table 2). Survival rate of seedlings from the M-nursery was also significantly higher than in seedlings from the other nurseries (Table 2). At the time of outplanting, pine seedlings from the N-nursery were significantly shorter $(p<0.05)$ (mean height $12.5 \mathrm{~cm}$ ) than seedlings from the $\mathrm{S}$ - and $\mathrm{M}$-nurseries, which were similar $(p>0.05)$ in height $(16.2$ and $15.7 \mathrm{~cm}$, respectively). $\mathrm{N}$-nursery seedlings were also significantly shorter at the end of the experiment. After four growing seasons, the largest root collar diameter and shoot height was for S-nursery pine seedlings (Table 2). Survival of pine seedlings did not differ significantly among different provenances.

Seedling needle chemical analysis showed similar values among different planting materials of both tree species, especially in concentration of macro elements (Table 3).
CHEMICAL COMPOSITION OF NEEDLES (MG/G) OF P. ABIES AND $P$. SYLVESTRIS SEEDLINGS AFTER FOUR GROWING SEASONS (OCTOBER 2009) IN A PLANTATION

\begin{tabular}{c|c|c}
\hline $\begin{array}{c}\text { Chemical } \\
\text { element }\end{array}$ & Spruce & Pine \\
\hline & S- / M- / N-nursery & S- / M- / N-nursery \\
$\mathrm{N}$ & $12.5 / 12.7 / 10.0$ & $13 / 13 / 14$ \\
$\mathrm{P}$ & $2.6 / 2.1 / 2.7$ & $2.3 / 2.3 / 2.0$ \\
$\mathrm{~K}$ & $7.8 / 5.8 / 8.4$ & $6.0 / 6.0 / 6.4$ \\
$\mathrm{Ca}$ & $6.2 / 5.2 / 5.7$ & $2.6 / 3.0 / 3.4$ \\
$\mathrm{Mg}$ & $1.6 / 1.4 / 1.4$ & $1.6 / 1.6 / 1.7$ \\
$\mathrm{~S}$ & $1.9 / 1.3 / 1.8$ & $1.7 / 2.0 / 1.9$ \\
$\mathrm{Fe}$ & $0.044 / 0.048 / 0.042$ & $0.045 / 0.050 / 0.036$ \\
$\mathrm{Mn}$ & $0.088 / 0.040 / 0.030$ & $0.110 / 0.088 / 0.096$ \\
$\mathrm{Zn}$ & $0.050 / 0.040 / 0.046$ & $0.064 / 0.050 / 0.056$ \\
$\mathrm{Cu}$ & $0.003 / 0.003 / 0.004$ & $0.003 / 0.004 / 0.006$ \\
$\mathrm{Mo}$ & $0.0004 / 0.0005 / 0.0004$ & $0.0003 / 0.0005 / 0.0006$ \\
$\mathrm{~B}$ & $0.013 / 0.011 / 0.011$ & $0.013 / 0.008 / 0.012$
\end{tabular}

Seven ECM morphotypes were identified for the analysed 49 spruce seedlings, from which 9 ECM fungal species were sequenced. Similarly, five ECM morphotypes were detected in 41 pine seedlings, which after sequencing were identified as 9 ECM fungal species. The mean number of ECM morphotypes per seedling was lower for both tree species from the N-nursery, compared to those from other nurseries (Table 2). Thelephora terrestris and Amphinema sp. was found on ECM root tips of both tree species. Pine seedlings from different forest nurseries had generally different ECM species associated with their roots (Table 4). Higher ECM diversity was on pine seedlings from the S-nursery than from the other two nurseries (Table 4). Members from the Atheliaceae family (Amphinema spp. and Tylospora asterophora) were the most common symbionts on spruce (Table 4). Spruce seedlings from the M-nursery were colonised by Amphinema sp., Clavulina sp. and Tuber sp. and their ECM community did not have any species in common

Table 4

RELATIVE ABUNDANCE (\%) OF ECM SPECIES IN 2009 ON SCOTS PINE ( $P$. SYLVESTRIS) AND NORWAY SPRUCE (P. ABIES) SEEDLINGS

\begin{tabular}{|c|c|c|c|c|c|c|c|c|c|}
\hline \multirow[t]{3}{*}{ Parameter / species } & \multirow[t]{3}{*}{ GenBank No. } & \multirow{2}{*}{\multicolumn{3}{|c|}{$\begin{array}{c}\text { Pine } \\
\text { Nurseries }\end{array}$}} & \multirow[t]{3}{*}{ Species } & \multirow[t]{3}{*}{ GenBank No. } & \multirow{2}{*}{\multicolumn{3}{|c|}{$\begin{array}{c}\text { Spruce } \\
\text { Nurseries }\end{array}$}} \\
\hline & & & & & & & & & \\
\hline & & $\mathrm{S}$ & $\mathrm{M}$ & $\mathrm{N}$ & & & $\mathrm{S}$ & $\mathrm{M}$ & $\mathrm{N}$ \\
\hline $\mathrm{n}$ of seedlings & & 20 & 14 & 7 & & & 20 & 20 & 9 \\
\hline Total number of species & & 5 & 2 & 3 & & & 4 & 3 & 5 \\
\hline Shannon diversity index & & 1.70 & 0.91 & 1.56 & & & 1.70 & 1.48 & 1.91 \\
\hline Amphinema sp. & KT447168 & 9.4 & - & - & Amphinema byssoides & KT447174 & 47.0 & - & 36.8 \\
\hline Phialocephala fortinii & KT447169 & 9.4 & - & - & Amphinema sp. & KT447175 & - & 43.8 & - \\
\hline Suillus bovinus & KT447170 & - & 33.3 & - & Cenococcum geophilum & KT447176 & 2.9 & - & 5.3 \\
\hline Suillus luteus & KT447171 & 9.4 & - & - & Clavulina sp. & KT447177 & - & 39.6 & - \\
\hline Suillus cf. variegatus & KT447172 & 9.4 & - & - & Cortinarius caninus & KT447178 & - & - & 21.1 \\
\hline Thelephora terrestris & KT447173 & - & - & 44.0 & Thelephora terrestris & & 38.2 & - & - \\
\hline Unid. basidiomycete & - & - & - & 28.0 & Tuber sp. & KT447179 & - & 16.7 & - \\
\hline Unid. Archaeorhizomycetales & - & - & 66.7 & 28.0 & Tylospora asterophora & KT447180 & 11.8 & - & 5.3 \\
\hline Unid. ascomycete & - & 62.5 & - & - & Wilcoxina mikolae & KT447181 & - & - & 31.6 \\
\hline
\end{tabular}


with those of spruce seedlings from other nurseries. In contrast, S- and N-nurseries had moderately similar ECM species composition (Sörensen index $=0.6$ ) and were dominated by Amphinema byssoides. Spruce seedlings of S-nursery had rather high colonisation by Thelephora terrestris and Tylospora asterophora, while N-nursery seedlings were mostly colonised by Wilcoxina mikolae and Cortinarius caninus (Table 4).

\section{DISCUSSION}

The results of the present study showed that survival, growth and ECM community in roots were in many cases tree species and/or provenance specific, indicating that genetic background of the seedlings largely determines both their survival and growth of the seedlings as well as composition of ECM fungal community in roots (Klavina et al., 2015). The higher shoot growth and survival rate of spruce seedlings from M-nursery in comparison to spruce seedlings from other nurseries might be related to their origin and the ECM species community in roots. Considering that promotion of stem growth is specific only for some ECM fungi (Stenström and Ek, 1990), the higher growth and survival rate of M-nursery seedlings might be due to the presence of specific ECM fungi, such as Tuber sp., Clavulina sp. and Amphinema sp. Among those species, Amphinema sp. was on both S-nursery pine and M-nursery spruce seedlings that showed the highest growth rate, suggesting that this species might be an indicator of seedling growth. However, in order to prove this more detailed studies or even inoculation experiments with this ECM species would be required. The observed slightly more diverse ECM community on spruce seedlings as compared to pine seedlings may be due to difference in seedling age and/or higher rate of ECM colonisation, which may be due to a larger proportion of spruce in the previous forest stand (Erland and Taylor, 2002).

Pine seedlings from the S-nursery had higher growth rate and greater abundance of Suilliod mycorrhizae (particularly Suillus luteus and S. variegatus) than seedlings from other nurseries. Positive effect of Suillus mycorrhizas, especially $S$. variegatus, on seedling growth and uptake of phosphorous and nitrogen has been reported (Wallander et al., 1997; Wallander, 2000; Leski et al., 2010). Relative abundance of $S$. variegatus on pine seedlings after four growing seasons was not high, but our previous observations before outplanting in 2006 (Latvian State Forest Research Institute "Silava", unpublished data) showed that S. variegatus was found more often on seedlings from the S-nursery than on M-nursery seedlings. Higher growth rate of S-nursery pine seedlings might be due to positive effects of nursery mycorrhiza, which likely contributed to the early growth of the trees (Gangé et al., 2006; Menkis et al., 2007). Needle chemical analysis of pine seedlings showed lower molybdenum concentration in S-nursery seedlings than in seedlings from the $\mathrm{M}$ - and N-nurseries. This element is strongly related to fertilisation (especially $\mathrm{N}$ supply) rate in forest nurseries (Anonymous, 2002), and therefore it is probable that a lower fertilisation rate in the S-nursery had promoted greater establishment and abundance of Suillus species. The observed differences in pine seedling growth and survival might also be related to differences in seed origin: S-nursery seedlings were cultivated from Eastern Latvia seed material, which is recommended for planting throughout the territory of Latvia (Anonymous, 1995; Neimane et al., 2009), while other provenances represented seed material from Central and Western Latvia, which is not recommended for forest regeneration in the region where the experimental site was located (State Forest Service, 1995).

We observed differences in tree performance after outplanting in association with seedling production in forest nurseries, thereby showing the importance of both nursery management practices and seed provenances. Lower survival rate, morphotype diversity and height growth was observed for both conifer species from the N-nursery. Among the observed ECM fungi, Suillus mycorrhizas were not detected on seedlings from the $\mathrm{N}$-nursery. Wilcoxina mikolae, which was shown to cause reduction of height growth (Leski et al., 2010), was only on seedlings from this nursery. The latter demonstrates that nursery practices may severely hamper or restrict root colonisation by ECM fungi during seedling production (Flykt et al., 2008) and consequently compromise seedling growth and development. We consider that the observed tendencies might be related to seedling origin. The $\mathrm{N}$-nursery had been established in the year 2006 and probably its practice and technique in producing sustainable planting material was still under development, resulting in the observed differences.

\section{CONCLUSION}

The present study showed several differences in survival, growth and mycorrhization of the containerised pine and spruce seedlings obtained as standard planting material form different forest nurseries. The study indicates that forest nursery practices and/or seedling provenance can significantly impact seedling growth after outplanting.

\section{ACKNOWLEDGEMENTS}

We gratefully acknowledge support from the Latvia's State Forests JSC and Riga Forests, LLC.

\section{REFERENCES}

Agerer, R. (1986-2006). Colour Atlas of Ectomycorrhizae. München, Germany, Einhorn-Verlag, Schwäbisch Gmünd.

Altschul, S. F., Madden, T. L., Schäffer, A. A., Zhang, J., Zhang, Z., Miller, W., Lipman, D. J. (1997). Gapped BLAST and PSI-BLAST: A new generation of protein database search programs. Nucl. Acids Res., 25, 3389-3402.

Anonymous (1995). Normative documents for forest regeneration [Meža atjaunošanas normatīvie akti]. Riga, State Forest Service. 44 pp. (in Latvian).

Anonymous (2002). Micronutrients - Molybdenum. Forest Nursery Notes -2002 Winter. Available at:

http://www.rngr.net/publications/fnn/2002-winter/micronutrients-molybdenum/ (accessed 7 August 2015). 
Anonymous (2011). R: A language and environment for statistical computing. R Foundation for Statistical Computing, Vienna. Vienna, R Foundation for Statistical Computing. R Development Core Team. Available at: http://www.R-project.org/ (accessed 5 December 2011).

Drozd, P. (2010). ComEcoPaC — Community Ecology Parameter Calculator. Available at:

http://prf.osu.cz/kbe/dokumenty/sw/ComEcoPaC/ComEcoPaC.xls (accessed 10 January 2012).

Erland, S., Taylor, A. F. S. (2002). Diversity of ecto-mycorrhizal fungal communities in relation to the abiotic environment. In: Van der Heijden, M. G. A., Sanders, I. (eds.). Mycorrhizal Ecology. Berlin, Springer, pp. $163-200$

Flykt, E., Timonen, S., Pennanen, T. (2008). Variation of ectomycorrhizal colonisation in Norway spruce seedlings in Finnish forest nurseries. Silva Fennica, 42 (4), 571-585.

Fowler, J., Cohen, L., Jarvis, P. (1998). Practical Statistics for Field Biology. $2^{\text {nd }}$ edn. New York, NY, Wiley. 259 pp.

Gailis, A. (1993). Norway spruce provenances in Latvia. In: Proceedings of IUFRO (S2.2-11) Symposium "Norway Spruce Provenances and Breeding”. Latvia, Latvian State Forest Research Institute "Silava", pp. 44-49.

Gagné, A., Jany, J. L., Bousquet, J., Khasa, D. P. (2006). Ectomycorrhizal fungal communities of nursery-inoculated seedlings outplanted on clear-cut sites in northern Alberta. Canadian J. For. Res., 36 (7), 1684-1694.

Klavina, D., Gaitnieks, T., Menkis, A. (2013). Growth and ectomycorrhizal community development of containerised and bare-root Pinus sylvestris and Picea abies seedlings outplanted on a forest clear-cut. Baltic Forestry, 19, 39-49.

Klavina, D., Zaluma, A., Pennanen, T., Velmala, S., Gaitnieks, T., Gailis, A., Menkis, A. (2015). Seed provenance impacts growth and ectomycorrhizal colonisation of Picea abies seedlings. Baltic Forestry, 21 (2), 184-191.

Kõljalg, U. et al. (2013). Towards a unified paradigm for sequence-based identification of Fungi. Mol. Ecol., 22 (21), 5271-5277.

Korkama, T., Pakkanen, A., Pennanen, T. (2006). Ectomycorrhizal community structure varies among Norway spruce (Picea abies) clones. New Phytologist, 171, 815-824.

Leski, T, Aučina, A., Skridaila, A., Pietras, M., Riepšas, E., Rudawska, M. (2010). Ectomycorrhizal community structure of different genotypes of Scots pine under forest nursery conditions. Mycorrhiza, 20, 473-481.

Le Tacon, F., Alvarez, I. F., Bouchard, D., Henrion, B., Jackson, M. R., Luff, S., Parlade, I. J., Pera, J., Stenström, E., Villeneuve, N., Walker, C. (1994). Variations in field response of forest trees to nursery ectomycorrhizal inoc- ulation in Europe. In: Read, D. J., Lewis, D. H., Fitter, A. H., Alexander, I. J. (eds). Mycorrhizas in Ecosystems. Wallingford, CAB, pp. 119-134.

Magurran, A. E. (1988). Ecological Diversity and Its Measurement. Princeton, NJ, Princeton University Press. 192 pp

Mead, R., Curnow, R. N. (1983). Statistical Methods in Agriculture and Experimental Miology. London, Chapman \& Hall. 335 pp.

Menkis, A., Lygis, V., Burokienè, D., Vasaitis, R. (2012). Establishment of ectomycorrhiza-inoculated Pinus sylvestris seedlings on coastal dunes following a forest fire. Baltic Forestry, 18, 33-40.

Menkis, A., Vasaitis, R. (2011). Fungi in roots of nursery grown Pinus sylvestris: Ectomycorrhizal colonisation, genetic diversity and spatial distribution. Microbial Ecol., 61, 52-63.

Menkis, A., Vasiliauskas, R., Taylor, A. F. S., Stenlid, J., Finlay, R. (2007). Afforestation of abandoned farmland with conifer seedlings inoculated with three ectomycorrhizal fungi - impact on plant performance and ectomycorrhizal community. Mycorrhiza, 17, 337-348.

Neimane, U., Veinberga, I., Ruṇǵis, D. (2009). Phenotypic and genetic aspects of geographical differences in Scots pine populations of Latvia [Parastās priedes populāciju ǵeogrāfisko atškirību fenotipiskās un ǵenētiskās īpašības Latvijas teritorijā]. Mežzinātne, 20 (53), 3-15 (in Latvian).

Nilsson, L. O., Wallander, H. (2003). Production of external mycelium by ectomycorrhizal fungi in a Norway spruce forest was reduced in response to nitrogen fertilization. New Phytologist, 158 (2), 409-416.

Óskarsson, H., Brynleyfsdóttir, J. (2009). The interaction of fertilization in nursery and field on survival, growth and the frost heaving of birch and spruce. Iceland Agricult. Res., 22 (1), 58-68.

Stenström, E., Ek, M. (1990). Field growth of Pinus sylvestris following nursery inoculation with mycorrhizal fungi. Canadian J. For. Res., 20, 914-918.

Velmala, S. M., Rajala, T., Haapanen, M., Taylor, A. F. S., Pennanen, T. (2013). Genetic host-tree effects on the ectomycorrhizal community and root characteristics of Norway spruce. Mycorrhiza, 23, 21-33.

Wallander, H. (2000). Uptake of P from apatite by Pinus sylvestris seedlings colonised by different ectomycorrhizal fungi. Plant Soil, 218, 249-256.

Wallander, H., Arnebrant, K., Ostrand, F., Kårén, O. (1997). Uptake of $15 \mathrm{~N}$-labelled alanine, ammonium and nitrate in Pinus sylvestris L. ectomycorrhiza growing in forest soil treated with nitrogen, sulphur or lime. Plant Soil, 195, 329-338.

White, T. J., Bruns, T., Lee, S., Taylor, J. (1990). Amplification and direct sequencing of fungal ribosomal RNA genes for phylogenetics. In: Innis, M. A., Gelfand, D. H., Sninsky, J. J., White, T. J. (eds.). PCR protocols: A Guide to Methods and Applications. San Diego, CA, Academic Press, Inc., pp. 315-322.

Ying, C. C. (1991). Preformance of Lodgepole pine provenances at sites in southwestern British Columbia. Silvae Genetica, 40, 215-223.

Received 2 January 2016

Accepted in the final form 26 July 2017

\section{DAŽĀDAS IZCELSMES PARASTĀS PRIEDES (PINUS SYLVESTRIS) UN PARASTĀS EGLES (PICEA ABIES) IETVARSTĀDU IEAUGŠANĀS SEKMES UN MIKORIZĀCIJA MEŽA ZEMĒS}

Darbā salīdzināti dažādas izcelsmes parastās priedes Pinus sylvestris un parastās egles Picea abies ietvarstādu augšanas rādītāji (virszemes daḷas garums, skuju kīmiskais sastāvs, sakṇu kakla diametrs, sakṇu mikorizācija un mikorizu veidojošos sēṇu sugu sastāvs) četrus gadus pēc izstādīšanas meža zemēs. Rezultāti liecina, ka kopumā ierīkotajā eksperimentā egḷ stādu ieaugšanās sekmes bija augstākas, salīdzinot ar priežu ietvarstādiem. Egḷ ietvarstādu saknēs dominēja Wilcoxina, Amphinema un Tylospora sēṇu veidotās mikorizas, savukārt priežu ietvarstādiem — Suillus un Thelephora sugu mikorizas. Kā egles, tā priedes ietvarstādu variantiem, kas uzrādīja vislabākās augšanas sekmes, konstatēta sakṇu mikorizācija ar Amphinema sp. Šì pētījuma rezultāti rāda, ka stādu audzēšanas tehnoloğijas dažādās kokaudzētavās, kā arī stādu izcelsme var būtiski ietekmēt stādu ieaugšanās sekmes un morfoloğiskos rādītājus, kā arī sakṇu mikorizāciju. 